\title{
Relative importance of the numerical productivity components of sows in French herds during 1977
}

\author{
C. LEGAULT \\ Station de Génétique quantitative et appliquée, \\ Centre national de Recherches zootechniques, I.N.R.A., \\ 78350 Jouy-en-Josas (France)
}

The average values of the components of the number of piglets reared per sow, per year of reproductive life $\left(\mathrm{P}_{n}\right)$ and per year of presence on the farm $\left(\mathrm{P}^{\prime}{ }_{n}\right)$ observed in 1977 in 3464 French pig herds were analysed taking into account the size of the herd. First of all it should be pointed out that although $P_{n}$ is as easy criterion to derive, it is of minor importance as compared to $\mathrm{P}^{\prime}{ }_{n}$ which is closer to the economic ruality. Four classes of herds were set up on the basis of the number $(\mathrm{N})$ of litters weaned during the course of the reference period:

- 93I herds with $20 \leqslant \mathrm{~N} \leqslant 50$,

- I 426 herds with $5 \mathrm{I} \leqslant \mathrm{N} \leqslant 100$,

- 762 herds with IOI $\leqslant \mathrm{N} \leqslant \mathrm{I} 80$,

- 345 herds with $\mathrm{N}>\mathrm{I} 80$.

A significant improvement of $\mathrm{P}_{n}$ and $\mathbf{P}^{\prime}{ }_{n}$ was observed as the herd size increased. Thus, as the number of litters weaned during the year was less than $5^{\circ}$ or greater than $180, \mathrm{P}_{n}$ and $\mathrm{P}^{\prime}{ }_{n}$ increased respectively from 18.3 to 20.0 and from I 5.9 to I 7.6 piglets weaned/sow. This improvement was due essentially to an acceleration in the thythm of reproduction as a result of a reduction of the milking period by 9 days, the age at first farrowing by 12 days, the weaning-fertilization period by 7 days and of the last weaning-culling period by 8 days. On the other hand, litter size was slightly smaller in the biggest herds (I0.0 vs I0.2) whereas the mortality rate was I per cent lower in these herds.

Multiple linear regression equations showed that whatever the herd size $\mathrm{P}^{\prime}{ }_{n}$ was determined by 4 significant variables in the following order: litter size at birth, mortality rate from birth to weaning, the last weaning-culling interval and, in 3 cases out of 4 , the length of the milking period. The age at first farrowing was ranked in the fifth place except in the second class where it was in the fourth place. The first two variables accounted for $3^{6}$ to 56 per cent of the variance of $\mathrm{P}^{\prime}{ }_{n}$ whereas the four significant variables together accounted for 53 per cent of the variance in the smallest herds and 76 per cent in the largest.

Taking into account the tendency for herds to become larger and more specialized, this study shows that from now our efforts should be directed towards an increase of the litter size at birth and a lowering of the mortality rate of the piglets.

\section{Results of an inquiry about the causes of sow culling}

\author{
J. JOSSE (1), M. LE DENMAT $\left({ }^{2}\right)$, Françoise MARTINAT-BOTTE $\left({ }^{3}\right)$, \\ J. SAULNIER $\left({ }^{2}\right)$, P. VANNIER $\left({ }^{3}\right)$, J.-C. VAUDELET $\left({ }^{2}\right)$ \\ (') Ministère de l'A gricultuve, Direction de la Qualité, \\ Services Vétérinaires, Station de Pathologie Porcine, \\ B.P. 9, 22440 Ploutragan (France) \\ (2) I.T.P., La Motte au Vicomte, B.P. 3, 35650 Le Rhew (France) \\ (3) Station de Physiologie de la Reproduction, \\ Centre de Recherches de Tours, I.N.R.A., \\ Nonzilly, 37380 Monnaie (France)
}

Several inquiries show that a relative constant percentage of sows ( 40 to $50 \mathrm{p}$. Ioo) are culled for causes related to reproduction. But it is impossible to verify the reason given by the farmer. We decided therefore, to compare in each sow the cause of culling given by the farmer with the 